\title{
AKTIVITAS ANTIOKSIDAN DARI METABOLIT SEKUNDER KAPANG ENDOFIT MANGROVE Aegiceras corniculatum
}

\author{
(The Antioxidant of Secondary Metabolites from Aegiceras corniculatum Mangrove Derived \\ Endophytic Fungi)
}

\author{
Siti Nurhalimah" ${ }^{1)}$, Siti Irma Rahmawati' ${ }^{2}$, Joko Hermanianto ${ }^{3)}$, Siti Nurjanah ${ }^{3)}$, Fauzia Nurul \\ Izzati $^{2)}$, Eris Septiana ${ }^{2)}$, Fauzy Rachman'), Bustanussalam ${ }^{2)}$, Yatri Hapsari' ${ }^{2)}$, Partomuan \\ Simanjuntak ${ }^{2}$, Masteria Yunovilsa Putra ${ }^{2)}$ \\ ${ }^{1}$ Graduate Student, IPB University, Bogor 16680, Indonesia \\ ${ }^{2}$ Research Center for Biotechnology, Indonesia Institute of Science, Cibinong 16911, Indonesia \\ ${ }^{3}$ Department of Food Science and Technology, IPB University, Bogor 16680, Indonesia \\ e-mail: nurhalimahsiti01@gmail.com
}

Diterima 16 Desember 2020, Revisi akhir 22 April 2021, Disetujui 28 Mei 2021

\begin{abstract}
ABSTRAK. Kapang endofit dari mangrove memiliki potensi dalam menghasilkan metabolit sekunder seperti antioksidan. Antioksidan merupakan senyawa yang banyak diaplikasikan dalam industri sebagai bahan untuk pembuatan produk di bidang pangan maupun kesehatan. Penelitian ini bertujuan untuk mengetahui potensi antioksidan kapang endofit dari mangrove species Aegiceras corniculatum. Sebanyak 8 isolat kapang endofit berhasil diisolasi, yaitu 2 isolat berasal dari daun, 3 isolat berasal dari buah dan 3 isolat berasal dari ranting. Di antara 8 isolat tersebut, hanya 1 isolat yang dihanyakan aktif sebagai antioksidan dengan nilai IC 50 sebesar 19,28 $\mu \mathrm{L} / \mathrm{mL}$, meskipun nilai ini masih lebih rendah dibandingkan vitamin $C$ yaitu sebesar 6,08 $\mu \mathrm{L} / \mathrm{mL}$. Hasil identifikasi kimia dengan menggunakan $G C$-MS menunjukkan beberapa senyawa kimia yang memiliki aktivitas aktioksidan di antaranya phenol,3,5-bis(1,1dimethylethyl), hexadecanoic acid, hexadecanoic acid methyl ester, malic acid, N-aminopyrrolidine, 9octadecanoic acid, methyl ester (E), benzeneethanol, 4-hydroxy, 1,2-benzenedicarboxylic acid, d-tyrosine, bis(2-methylpropyl) ester 1-nonadecene dan heneicosane. Isolat kapang endofit diidentifikasi dengan penanda Internal Transcribed Spacer (ITS) dan memiliki kemiripan tertinggi dengan Microdochium sp.
\end{abstract}

Kata kunci: Aegiceras corniculatum, antioksidan, kapang endofit, mangrove, Microdochium sp

\begin{abstract}
Mangrove endophytic fungi potentially produce secondary metabolites such as antioxidant. Antioxidants are compounds that are widely applied in the industry as an ingredient in the manufacture of products in the food and health sector. In this study, we investigated the antioxidant potential of secondary metabolites from fungal endophytic of mangrove species Aegiceras corniculatum. A total of eight endophytic fungi were successfully isolated, two isolates from leaf, three isolates from fruit and three isolates from twig. Between the isolates obtained, only one isolated was active as the antioxidant with IC $_{50}$ value $19.28 \mu \mathrm{L} / \mathrm{mL}$ eventhough still lower than the standard ascorbic acid $(6.08 \mu \mathrm{L} / \mathrm{mL})$. The results of chemical identification using GC-MS showed several chemical compounds that have antioxidant activity including phenol,3,5-bis(1,1-dimethylethyl), hexadecanoic acid, hexadecanoic acid methyl ester, malic acid, N-aminopyrrolidine, 9-octadecanoic acid, methyl ester (E), benzeneethanol, 4-hydroxy, 1,2benzenedicarboxylic acid, d-tyrosine, bis(2-methylpropyl) ester 1-nonadecene dan heneicosane. The selected fungal endophytic isolated were identified using molecular Internal Transcribed Spacer (ITS) marker and has a high taxonomy similarity with Microdochium sp.
\end{abstract}

Keywords: Aegiceras corniculatum, antioxidant, endophytic fungi, mangrove, Microdochium sp 


\section{INTRODUCTION}

Indonesia has the largest mangrove forest in the world. It has 202 species of mangrove that scattered along the country (Wardani et al., 2016). Mangrove plants have benefit as it contains secondary metabolites. Condition of mangrove's mixed ecosystem causes mangrove fungi to live in extreme environment. This situation potentially produces numerous compounds, including bioactive metabolites (Debbab et al., 2013; Hamed et al., 2015). Secondary metabolites from mangrove can provide antimicrobial, antimalarial, anticancer and antioxidant materials (Sari \& Hasibuan 2017).

Mangrove plants probably contain several endophytic microbes on its tissues that can produce secondary metabolites compounds. Endophytic microbes from mangrove are also part of the second biggest marine microbe group (Zhou et al., 2018). This kind of endophytic microbes, especially endophytic fungi has an essential role in supporting ecosystem of mangrove on its cycles. It is proven that endophytic fungi are the source of natural compounds that have high biological activity and level structural diversity (Vijaya, 2017). In an ideal way, metabolites compounds from endophytic fungi have a large number of activities in comparison to its host plant (Strobel et al., 2004).

The utilization of endophytic fungi from mangrove is potentially to be observed The production of secondary metabolite using endophytic microbes has several advantages, such as short life cycles, so production process is simpler as it does not require big space as a planting area. Moreover, bioactive resources from plant such as fruit, peel, tissue, leaf and stem can destroy the plant itself in a time. Also, the process of collecting the substances that is done repeatedly can cause crisis and extinction for several species of plants (Deshmukh et al., 2018).

Endophytic fungi can produce secondary metabolite based on its bioactivity and chemical structure such as antioxidant (Zhou et al., 2018; Rahmawati et al., 2019), antibacterial (Handayani et al., 2017; Mukhlis et al., 2018; Prihanto et al., 2011), antimicrobial (Basha et al., 2012), antivirus (Rajamanikyam et al., 2017; Zhang et al., 2011), antidiabetic and anti-inflammatory (Rajamanikyam et al., 2017). Antioxidants are compounds that mostly used as industrial resources in food and health sector. It can prevent radical oxidation and reduce oxidative stress (Chaudhary et al., 2015). Moreover, antioxidant inhibits peroxidation by transfering electron or hyrogen atom of free radicals in order to balance the compounds (Chi et al., 2015).
Several synthetic antioxidants can be used to inhibit oxidation on food containing oils such as butylated hydroxytoluene (BHT), butylated hydroxyanisole (BHA) dan tert-butylhydroquinone (TBHQ). However, the use of synthetic antioxidants is limited as it has health risk such as protein and DNA damage, toxicity, etc. (Zhou et al., 2018). As the result, it is a need to find antioxidants sources that are safer and made from sustainable resource. Therefore, the research related to antioxidants from endophytic fungi is essential to be conducted. This research aimed to isolate endophytic fungi of Aegiceras corniculatum to analyze its antioxidant activity and identify chemical that is contained in secondary metabolite produced by isolated endophytic fungi. Furthermore, molecular identification was carried out on selected endophytic fungi isolates.

\section{METHOD}

\section{Isolation of Endophytic Fungi (Modified Handayani et al., 2017)}

The fresh leaf, fruit and twig of mangrove species Aegiceras corniculatum were collected from Segara Anakan, Central Java, Indonesia. It washed with running water for 10 minutes. The sample is cut into two pieces with a length of the pieces $1 \mathrm{~cm}$. Then, the part of sample is sterilized by dipping in $70 \%$ ethanol for $1 \mathrm{~min}$, put into NAOCL $5,3 \%(\mathrm{w} / \mathrm{v})$ for 5 minutes and dipped again in $70 \%$ ethanol (v/v) for 30 seconds. Each pieces were placed on potato dextrose agar (PDA) media and incubated at $27{ }^{\circ} \mathrm{C}$ for 7 days. Morphologically different results were transferred to the PDA media and incubated for 7 days at room temperature. (not tilted, PDA with petri dish)

\section{Fermentation and Extraction of Isolated Endophytic Fungi (Rachman et al., 2018)}

Fermentation is carried out by taking a loop of mold that grows on a plate containing PDA media and put in an erlenmeyer container containing 100 $\mathrm{mL}$ PDB media. It was incubated using shaking incubators at $120 \mathrm{rpm}$ in 14 days, approximately. Extraction was carried out after cultivation for 14 days. The extraction process itself was done using ethyl acetate to separate between the filtrate and the growing mold mycelia. Separation using a vacuum filter using filter paper that has been weighed before. After being tested, the mold mycelia were dried using an oven at $60{ }^{\circ} \mathrm{C}$ for 24 hours. The filtrate was partitioned using a separating funnel with 1:1 ethyl acetate solvent. Extraction was 
carried out 3 times. After partitioning, the filtrate is evaporated using a rotary evaporator until the liquid thickens. After that, the drying is done again to evaporate all the ethyl acetate in the mold extract. The final result of the mold extract was weighed and tested for its antioxidant activity.

\section{Analysis of Antioxidant (Rachman et al., 2018)}

Antioxidant activity of extracted isolated endophytic fungi was analyzed to obtain potential isolate that active as an antioxidant. The antioxidant inhibition test was conducted through 2,2-difenil1-pikrilhidrazil (DPPH) method at concentration level $100 \mu \mathrm{L} / \mathrm{mL}$. The stock solution was made in $1000 \mu \mathrm{L} / \mathrm{mL}$, then pipette as much as $0.3 \mathrm{~mL}$ and reacted with DPPH $0.4 \mathrm{mM}$ as much as $0.6 \mathrm{~mL}$ and added $2.1 \mathrm{~mL}$ methanol so that the total mixture becomes $3 \mathrm{~mL}$. The solution is incubated at $37^{\circ} \mathrm{C}$ for 30 minutes. The solution was incubated at $37^{\circ} \mathrm{C}$ in 30 minutes. After that, the solution was measured using spectrophotometer with $517 \mathrm{~nm}$ wavelength. The inhibition was calculated using equation:

$$
\text { Percentage of DPPH scavenger }=\frac{A-B}{A} \times 100 \%
$$

\section{A: control absorbance}

B: extract absorbance

Next, $\mathrm{IC}_{50}$ of the extract of ethyl acetate which determined as active antioxidant were analyzed. The antioxidant activity was conducted through DPPH method at concentrations level of 5, 20, 25 and $50 \mu \mathrm{L} / \mathrm{mL}$.

\section{Analysis of Chemical Compounds for Potential Endophytic Fungi (Druzian et al., 2019)}

Analysis of chemical compounds was carried out using gas chromatography-mass spectrometry (GS-MS) Shimadzu type GC-100 Plus Series with Rtx-5MS capillary column (diameter $0.25 \mu \mathrm{m}$, length $30 \mathrm{~m}$, thickness $0.25 \mu \mathrm{m}$ ). Other conditions in GC-MS include carrier gas using Helium UHP (Ultra High Pure), Split $\left(200{ }^{\circ} \mathrm{C}\right)$, flow control mode: Pressure, column flow: $1.08 \mathrm{~mL} / \mathrm{min}$ and oven temperature: 60 to $235^{\circ} \mathrm{C}$ ).

\section{Molecular Identification of Potential Endophytic Fungi}

Molecular identification was done by using molecular marker Internal Transcribed Spacer (ITS). DNA isolation of fungal using ZR Fungal Bacteria DNA Kit (Zymo Research, D6005). The stages of DNA amplification are by making a volume of $25 \mu \mathrm{L}$ PCR master mix containing $9.5 \mu \mathrm{L}$ alkaline free water, $12.5 \mu \mathrm{L} 2 \mathrm{x}$ My Taq HS Red Mix (Bioline, BIO-25047), $1 \mu \mathrm{L}$ DNA template, $1 \mu \mathrm{L} 20$ $\mu \mathrm{mol} / \mu \mathrm{L}$. Primer uses ITS 1 (5'TCCGTAGGTGAACCTGCGG-3') as the forward primer and ITS 4 (5'TCCTCCGCTTATTGATATGC-3') as the reverse primer. The reactions carried out in the amplification process were 35 cycles with 3 stages, pre-denaturation at $95^{\circ} \mathrm{C}$ for 1 minute, denaturation at $95{ }^{\circ} \mathrm{C}$ for 15 seconds, annealing at $52{ }^{\circ} \mathrm{C}$ for 15 seconds and extension at $72{ }^{\circ} \mathrm{C}$ for 45 seconds. PCR product were sent for sequencing at the $1^{\text {st }} \mathrm{BASE}$ in Malaysia, Apical Scientific Sdn Bhd. The result of DNA sequencing was analyzed with Base basic local aligment search tool (BLAST) on the National Centre for Biotechnology Information (NCBI).

\section{RESULT AND DISCUSSION Isolation of Endophytic Fungi}

Isolation of endophytic fungi from the mangrove Aegiceras corniculatum were successfully isolated from leaves, fruit and twig by using PDA. The morphological characters of the endophytic fungi that grow on the media are observed in plain view. Morphological characters observed included surface color and reverse, texture, topography and exudates. Morphologically different fungi were each transferred to PDA media to obtain pure isolates. Eight pure isolates were obtained which 2 isolates were from leaves (Figure 1), 3 isolates from fruit (Figure 2) and 2 isolates from twigs (Figure 3). 
Table 1. Morphological characters of endophytic fungi on the leaves, fruits and branches of the mangrove aegiceras corniculatum

\begin{tabular}{|c|c|c|}
\hline No & Isolate Code & Morphological characters \\
\hline 1 & DD1 & $\begin{array}{l}\text { Circular growth pattern, slightly brownish white surface color, brownish yellow } \\
\text { reverse color, velvety texture, verrugose topography and no c points }\end{array}$ \\
\hline 2 & DD2 & $\begin{array}{l}\text { Circular growth pattern, clean white surface color, yellowish-white reverse color, } \\
\text { cotton-like texture, topography has button-like protrusions in the center of the } \\
\text { colony, forming radial lines and no exudates points }\end{array}$ \\
\hline 3 & DBU1 & $\begin{array}{l}\text { Circular growth pattern, slightly yellowish white surface color, brownish-white } \\
\text { reversal color, hyphae texture almost long like wool cloth, has a protrusion in the } \\
\text { center of the colony, does not form radial lines and there are no exudates points }\end{array}$ \\
\hline 4 & DBU2 & $\begin{array}{l}\text { Circular growth pattern, white surface color, brownish yellow reverse color, } \\
\text { smooth hyphal texture and overall more transparent, verrugose topography, does } \\
\text { not form radial lines and there are no exudates points }\end{array}$ \\
\hline 5 & DBU3 & $\begin{array}{l}\text { Circular growth pattern, white surface color, yellowish-white reversal color, long } \\
\text { and dense textures of hyphae like cotton, have a prominent area in the center of } \\
\text { the colony, do not form radial lines and there are no exudates points }\end{array}$ \\
\hline 6 & DR1 & $\begin{array}{l}\text { Circular growth pattern, white surface color, yellowish-white inverse color, dense } \\
\text { texture like cotton, no radial lines and no exudates points. }\end{array}$ \\
\hline 7 & DR2 & $\begin{array}{l}\text { Circular growth pattern, slightly brownish white surface color, yellowish-white } \\
\text { inverted color, smooth hyphal texture, short like transparent, colonies have } \\
\text { irregular grooves and have exudates points }\end{array}$ \\
\hline 8 & DR3 & $\begin{array}{l}\text { Circular growth pattern, white surface color and brownish part, brownish white } \\
\text { reverse color, woolen-like texture, colony has irregular grooves, does not form } \\
\text { radial lines and there are no exudates points. }\end{array}$ \\
\hline
\end{tabular}
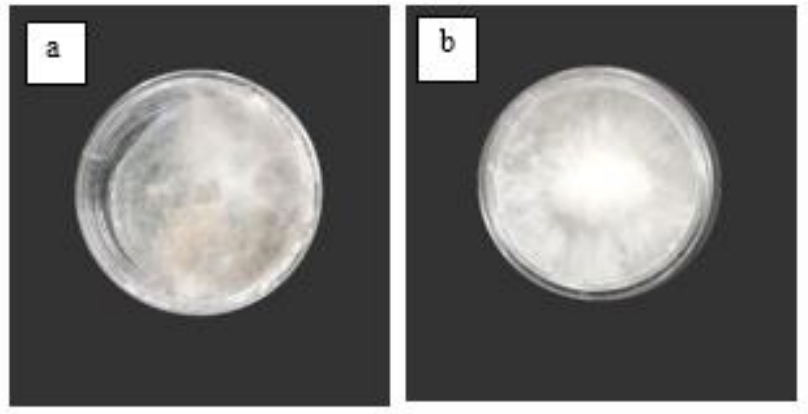

Figure 1. Isolated fungi from the leaf of mangrove Aegiceras corniculatum; a) Isolate DD1, b) Isolate DD2
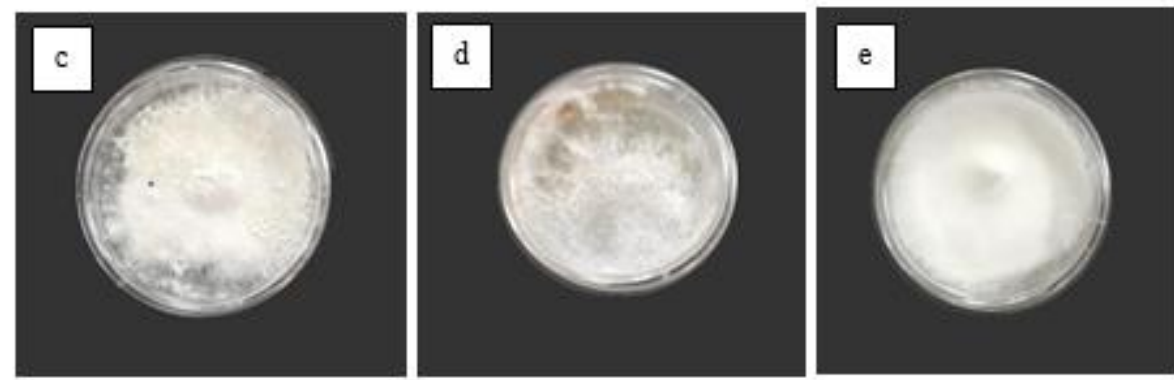

Figure 2. Isolated fungi from the fruit mangrove Agieceras corniculatum: c) Isolate DBU1, d) Isolate DBU2, e) Isolate DBU3 

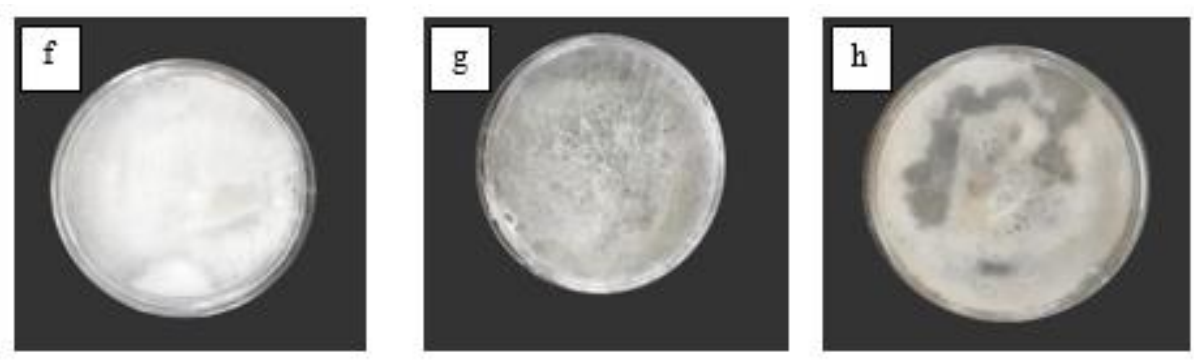

Figure 3. Isolated fungi from the twig of mangrove Agieceras corniculatum; f) Isolate DR1, g) Isolate DR2, h) Isolate DR3

In previous study, 24 endophytic taxa, 12 from its leaf and 17 from its twig of mangrove Aegiceras corniculatum in South China (Li et al., 2016). There were several isolates that can be found from species of mangrove in Indonesia. Rhizopora apiculata from Tanjung Api-Api obtained three isolated that has different characateristics, seven isolated from its roots, leaf and stems (Mukhlis et al., 2018). There were 12 strains of endophytic fungi from roots, leaf dan stems of Sonneratia griffithii (Handayani et al., 2017). Moreover, endophytic fungi of Rhizopora mucrona that was taken from Sidorajo obtained 12 isolates, three from leaf, four from stem and five from root (Prihanto et al., 2011). The difference in the number of isolates obtained in each plant is thought to be due to environmental factors, namely habitat conditions. Environmental conditions in each plant are different and affected to interaction between endophytic fungi and their host plants. In addition, the type of isolate obtained was different from each plant so that it would affect its morphological characteristics. Environmental factors such as season, location and species can influence the diversity or frequency of endophytic fungi in their host plants (De Souza Sebastianes et al., 2013). In addition, other factors such as fragment size, plant part and identification difficulties can affect the differences in the number of endophytic species found in each isolated host plant (Costa et al., 2012). Host species also contribute to mold formation, such as in mangroves where the acidity index between plant species is relatively low even though they grow in the same area (Costa et al., 2012).

\section{Fermentation and Extraction of Isolated Endophytic Fungi}

Fermentation is done to grow molds so that they can produce secondary metabolites. The fermentation process in endophytic fungi occurs in the statistical phase which generally occurs until day 14. The statistical phase is the right time for the fungi to produce secondary metabolites optimally (Basha et al., 2012) and then extracted to obtain pure secondary metabolites..

According to the results, DD1 isolate had the highest extract yield $(27.45 \mathrm{mg})$ and DR1 isolate had the lowest yield $(12.85 \mathrm{mg})$ in $100 \mathrm{~mL}$ PDB media (Figure 4). Rachman et al. (2018) reported the yield the ethyl acetate extract of endophytic fungi isolated from cinnamon twigs. The highest yield (w/v) was $0.045 \%$ in Cb.Gm.B9 isolates and the lowest yield was $0.012 \%$ in Cb.Gm.B2 and Cb.Gm.B6 isolates (Rachman et al., 2018). The yield of endophytic fungi extract derived from the leaves of Markhamia tomentosa was reported by Ibrahim et al. (2017), where ethyl acetate exract of $554,180,437$ and $480 \mathrm{mg}$ in $200 \mathrm{mg}$ of solid rice medium were obtained. Secondary metabolite extract obtained from isolates Jatropha curcas namely 750, 590, 56, 321 and $501 \mathrm{mg}$ in $1200 \mathrm{~mL}$ of media (Kumar et al., 2013). The yield produced from extracts of secondary metabolites from mangroves Avicennia marina and Xylocarpus granatum is $17 \mathrm{mg}$ from leaves, $12-15 \mathrm{mg}$ from stems and 7-14 mg from roots (Rahmawati et al., 2019). 
S. Nurhalimah, S. I. Rahmawati, J. Hermanianto, S. Nurjanah, F. N. Izzati, E. Septiana, F. Rachman, Bustanussalam, Y. Hapsari, P. Simanjuntak, M. Y. Putra / JBI 12(1) 2021, 51-61

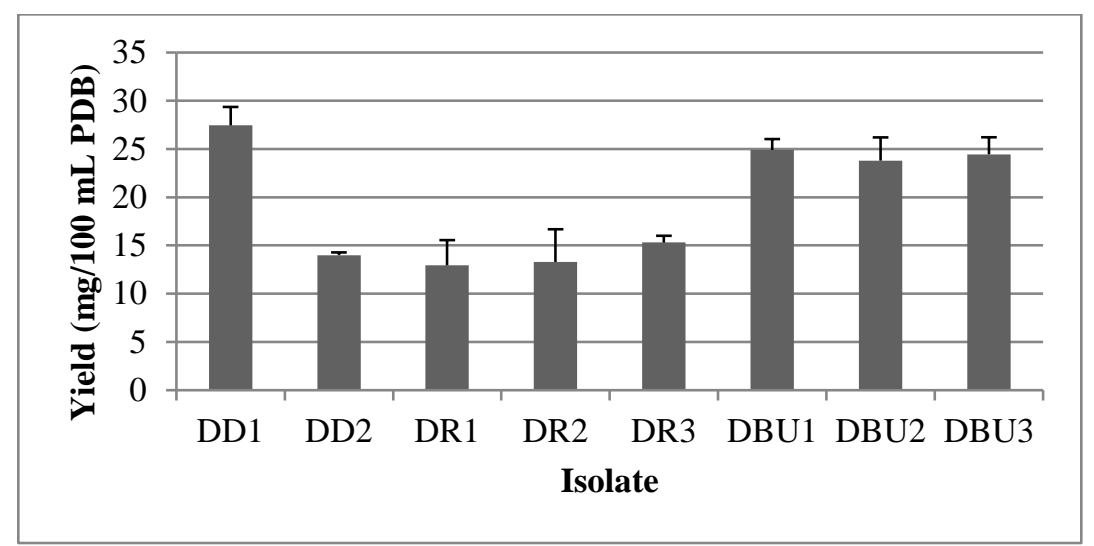

Figure 4. Extract yield of secondary metabolites mangrove Aegiceras corniculatum endophytic fungi endophytic fungi by ethyl acetate, whereas DD1, DD2 are fungi from leaves; DR1, DR2, DR3 are fungi from twig; DBU1, DBU2, DBU3 fungi from fruits. Data showed in the mean \pm SD $(n=3)$

\section{Analysis of Antioxidant of the Extract}

The antioxidant inhibition test was conducted at $100 \mu \mathrm{L} / \mathrm{mL}$ concentration level to obtain the inhibition percentage. The result showed that all of the endophytic fungi isolated which were successfully isolated had an inhibitory of DPPH scavenger. However, there was only one endophytic fungi (DBU3 isolate showed inhibition over $50 \%$ at concentration used (Table 2). The activity of antioxidant is considered active if it is able to inhibit free radical more than $80 \%$, moderate if it inhibits $50-80 \%$ of free radical and inactive if the inhibition level less than 50\% (Widowati et al., 2016).

Table 2. Secondary metabolite antioxidant capacity of secondary metabolites produces by endophytic fungi from

\begin{tabular}{ccc}
\multicolumn{3}{c}{ Aegiceras corniculatum } \\
\hline No & Isolate & Percentage inhibition of DPPH scavenger $(\%)$ \\
\hline 1 & DD1 & 22.20 \\
2 & DD2 & 10.09 \\
3 & DBU1 & 41.64 \\
4 & DBU2 & 19.17 \\
5 & DBU3 & 89.80 \\
6 & DR1 & 7.45 \\
7 & DR2 & 4.18 \\
8 & DR3 & 31.58 \\
\hline
\end{tabular}

Abbreviations for percentage of DPPH scavenger are the same as in Figure 4

Ethyl acetate extract which had an inhibition more than $50 \%$ were analyzed for $\mathrm{IC}_{50}$ The antioxidant activity was further tested using 5, 10, 25 dan $50 \mu \mathrm{L} / \mathrm{mL}$ level of concentration. Table 2 shows the higher level of concentration that is used, there will be an escalation of the percentage of the inhibition level. According to the result, value of the extract of antioxidant from DBU3 isolate on $\mathrm{IC}_{50}$ is $19,28 \mu \mathrm{L} / \mathrm{mL}$.

Table 3. IC $_{50}$ value of DBU3 isolate and control (ascorbic acid)

\begin{tabular}{cccc}
\hline Sample & Concentration $(\boldsymbol{\mu L} / \mathbf{m L})$ & $\begin{array}{c}\text { Percentage inhibition of DPPH } \\
\text { scavenger }(\%)\end{array}$ & $\mathbf{I C}_{\mathbf{5} \mathbf{0}}(\boldsymbol{\mu L} / \mathbf{m L})$ \\
\multirow{2}{*}{ DBU3 } & 5 & 39.51 & \\
& 10 & 44.47 & 19.28 \\
& 25 & 53.48 & \\
Ascorbic Acid & 50 & 71.45 & 6.08 \\
& 3 & 39.28 & \\
\hline
\end{tabular}

DBU3 is selected isolate, from fruit mangrove Aegiceras corniculatum 
According to the result, it can be concluded that DBU3 endophytic fungi isolated has active antioxidant activity. The $\mathrm{IC}_{50}$ on the antioxidant activity test were divided into several groups very active if it has $\mathrm{IC}_{50}<10 \mathrm{mg} / \mathrm{L}$, active if it reach the value of $\mathrm{IC}_{50}<100 \mathrm{mg} / \mathrm{L}$ and inactive if the value of $\mathrm{IC}_{50}>100 \mathrm{mg} / \mathrm{L}$ (Çam and Durmaz 2009). Therefore, research conducted by Zhou et al. (2018), there were 2 isolates, HHL55 (Cytospora rhuzophorae) and HHL38 (Seridium ceratosporum) from mangrove Rhizophora stylosa which had the most potential as antioxidants with $\mathrm{IC}_{50}$ values 0,33 $\pm 0,02$ and $0,37 \pm 0,02 \mathrm{mg} / \mathrm{mL}$. Antioxidant activity produced from the mangrove endophytic fungi Aspergillus sp. Y16 has an IC value of $1.45 \mathrm{mg} / \mathrm{mL}$ (Chen et al., 2011). Endophytic fungi from the mangrove fruit of Acanthus ilicifolius L produced $\mathrm{IC}_{50}$ values ranging from 10,2 to $15,3 \mu \mathrm{g} / \mathrm{mL}$ in 4 components resulting from fermentation (Yan et al., 2020). Bioactivity that can be produced by endophytic fungi is influenced by environmental conditions. Secondary metabolites produced by endophytic fungi are a response to environmental stress, so that different environments may affect the conditions of endophytic fungi in producing secondary metabolite compounds. Different conditions such as salinity, pressure and temperature in marine organisms can produce different and unique natural product potentials in each species (Hamed et al., 2015). In addition, factors such as season, age, environment and location can affect the biological compounds produced by endophytic fungi (Strobel et al., 2004).

\section{Identification of chemical compounds}

Analysis of Gas Chromatography Mass Spectroscopy (GC-MS) indicated 50 compounds that were contained in ethyl acetate extract. There were only 22 compounds that have similarity value more than $80 \%$ according to library bank NISTI4.lib (Table 4).

Table 4. The chemical compound secondary metabolites of DBU3 isolate from GC-MS

\begin{tabular}{|c|c|}
\hline Retention Time (minutes) & Compound according library bank \\
\hline 8.5 & Malic Acid \\
\hline 11.0 & Hexane-1,3,4-triol, 3,5- dimethyl- \\
\hline 10.0 & N-Aminopyrrolidine \\
\hline 11.7 & dl-Mevalonic acid lactone \\
\hline 14.1 & Benzeneethanol, 4- hydroxy- \\
\hline 14.4 & 2,6,10- Trimethyltridecane \\
\hline 15.3 & Eicosane \\
\hline 17.3 & Phenol, 3,5-bis(1,1-dimethylethyl)- \\
\hline 18.2 & d-Tyrosine \\
\hline 18.6 & 9-Tricosene, $(\mathrm{Z})$ - \\
\hline 18.7 & Heneicosane \\
\hline 18.9 & Pentadecanoic acid \\
\hline 19.1 & i-Propyl 12-methyltetradecanoate \\
\hline 19.6 & 1,2- Benzenedicarboxylic acid, bis(2- methylpropyl) ester \\
\hline 20.1 & Hexadecanoic acid, methyl ester \\
\hline 20.2 & Pyrrolo [1,2- a] pyrazine-1,4-dione, hexahydro-3-(2-methylpropyl)- \\
\hline 20.3 & Eicosane, 2,4- dimethyl- \\
\hline 20.4 & n-Hexadecanoic acid \\
\hline 20.6 & Phthalic acid, isobutyl non-5-yn-3-yl ester \\
\hline 20.8 & 1-Nonadecene \\
\hline 20.9 & 9-Octadecanoic acid, methyl ester, (E)- \\
\hline 31.9 & Bis(2-ethylhexyl) phthalate \\
\hline
\end{tabular}

Based on the result of chemical profiling, it was suspected that active antioxidant compound on extract ethyl acetate produce by DBU3 isolate is phenol,3,5-bis(1,1-dimethylethyl) and 
benzeneethanol, 4-hydroxy- which was a part of phenolic compounds. According to the research that is conducted by Wei et al. (2011) it is reported that mangrove Aegiceras Corniculatum extract using ethyl acetate perform as a good antioxidant, especially on phenolic component. Other components that are considered to be involved an antioxidant activity from DBU3 isolate are hexadecanoic acid and octadecanoic acid as it has strong antioxidant activity (Patra et al., 2015). Apart from acting as an anticancer, anti-inflammatory and antimicrobial role, 1,2-benzenedicarboxylic acid compounds, bis (2-methylpropyl) ester have bioactivity as antimicrobials and antioxidants (Asghar et al., 2011; Ezhilan \& Neelamegam, 2011). The bis (2-ethylhexyl) phthalate compound is one of the compounds that has antioxidant activity (Asghar et al., 2011). Eicosane, 1-Nonadecene, Hexadecanoic acid and Heneicosane are included in compounds that have antioxidant activity (Premathilaka \& Silva, 2016). The octadecanoid acid methyl ester compound or stearic acid ester is also included in compounds that have antioxidant activity (Rahman et al., 2014). Another compound, tyrosol, found in endophytic fungi of GFV1 and GFM12 isolates has strong antioxidant activity (Radhakrishnan, 2017). Compounds of [1, 2-A] pyrazine-1, 4-dione, hexahydro-3- (2methylpropyl)- found in mangroves Streptomyces $s p$. VITMK isolates are nontoxic compounds that have potential as antioxidants that can ward off free radicals (Manimaran \& Krishnan, 2017). The Naminopyrrolidine compound which is included in the amine group has activity as an antioxidant (Tavadyan et al., 2017). Malic acid compounds show high antioxidant activity and can inhibit the lipase enzyme (Alakolanga et al., 2015). Bioactivity that can be produced by endophytic fungi is influenced by environmental conditions. Secondary metabolites produced by endophytic fungi are a response to environmental stress, so that different environments may affect the conditions of endophytic fungi in producing secondary metabolite compounds.

\section{Molecular Identification of Endophytic Fungi}

Molecular Identification for DBU3 sample was conducted using ITS. The result of electrophoresis of PCR DNA product of endophytic fungi showed the formation of a single tape that proves that the process of DNA isolation was successful. Marker that was used to read the result during the electrophoresis uses DNA marker $1 \mathrm{~kb}$.
It also showed the location of the DBU3 sample tape which around 600 base pair (Figure 5).
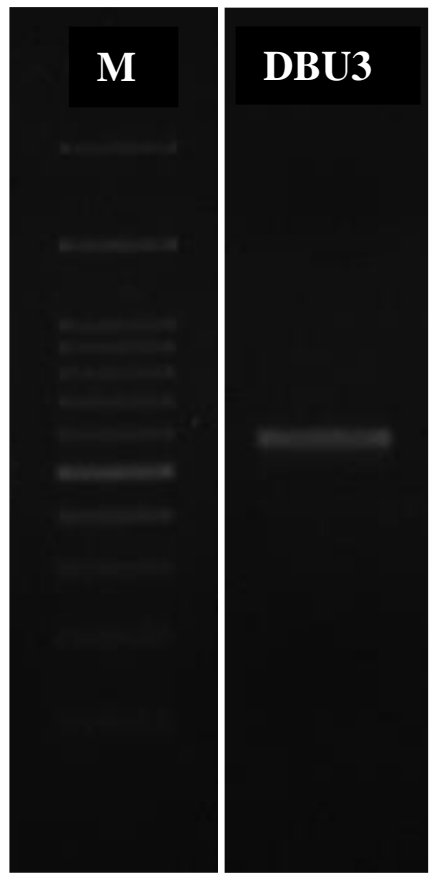

Figure 5. PCR Product from endophytic fungi DBU3 isolate with ITS 1 and ITS 4. DNA Marker $1 \mathrm{~Kb}$.

Based on the BLAST results from the sequencing obtained, the endophytic fungi of DBU3 isolates was identified as Microdochium $s p$. Microdochium is a species known as snow mold. Many species of Microdochium were identified in aquatic or marine environments (Liu et al., 2016). Several species of Microdochium are pathogens in plants. One group of Microdochium that causes diseases in plants such as Microdochium bolleyi which causes root necrosis and damage to grass (Hong et al., 2016), Microdochium paspali species are known to produce seashore paspalum in Paspalum vaginatum (Zhang et al., 2015). Some species from the Microdochium group are nonpathogenic and some are endophytic, such as Microdochium lycopodinum and Microdochium phragmitis which are isolated from plants that do not cause negative effects (Ernst et al., 2011). Some of the endophytes found include Microdochium sp in Rhoe spathacea roots from nurseries in Banten Indonesia (Alvin et al., 2016) and wheat in China (Gagkaeva et al., 2020). Microdochium lycopodinum species found in plants as endophytes include the leaves of Lycopodium annotinum in Austria (Hernándes-Restrepo et al., 2016). Microdochium sp found in roots extracted with ethyl acetate has antibacterial activity that can 
inhibit Pseudomonas aeruginosa, Staphylococcus aureus and Escherichia coli (Alvin et al., 2016).

\section{CONCLUSION}

Endophytic fungi that is successfully isolated from mangrove Aegiceras corniculatum obtained eight isolates from its leaf, fruit and twig. The selected isolated has the highest inhibiton of DPPH scavenger with the $\mathrm{IC}_{50}$ value $19.28 \mu \mathrm{L} / \mathrm{mL}$. This research discovers sustainable use of species especially endophytic fungi from mangrove as material for bioproduction of antioxidant.

\section{REFERENCES}

Alakolanga, A. G. A. W., Kumar, N. S., Jayasinghe, L., \& Fujimoto, Y. (2015). Antioxidant property and $\alpha$ -glucosidase , $\alpha$-amylase and lipase inhibiting activities of Flacourtia inermis fruits : characterization of malic acid as an inhibitor of the enzymes. Journal of Food Science Technology. https://doi.org/10.1007/s13197-015-1937-6

Alvin, A., Kalaitzis, J. A., Sasia, B., \& Neilan, B. A. (2016). Combined genetic and bioactivity-based prioritization leads to the isolation of an endophyte-derived antimycobacterial compound. Journal of Applied Microbiology, 120, 1229-1239. https://doi.org/10.1111/jam.13062

Asghar, S. F., Habib-ur-Rehman, Choudahry, M. I., \& Atta-ur-Rahman. (2011). Gas chromatographymass spectrometry (GC-MS) analysis of petroleum ether extract (oil) and bio-assays of crude extract of Iris germanica. International Journal of Genetics and Molecular Biology, 3(August), 95-100.

Basha, N. S., Ogbaghebriel, A., Yemane, K., \& Zenebe, M. (2012). Isolation and screening of endophytic fungi from Eritrean traditional medicinal plant Terminalia brownii leaves for antimicrobial activity. International Journal of Green Pharmacy, March, 40-44. https://doi.org/10.4103/09738258.97124

Çam, M., Hisil, Y., \& Durmaz, G. (2009). Classification of eight pomegranate juices based on antioxidant capacity measured by four methods. Food Chemistry, 112(2009), 721-726. https://doi.org/10.1016/j.foodchem.2008.06.009

Chaudhary, S., Chandrashekar, K. S., Pai, K. S. R., Setty, M. M., Devkar, R. A., Reddy, N. D., \& Shoja, M. H. (2015). Evaluation of antioxidant and anticancer activity of extract and fractions of Nardostachys jatamansi DC in breast carcinoma. BMC Complementary and Alternative Medicine, 15(1), 50 .

Chen, Y., Mao, W., Tao, H., Zhu, W., Qi, X., Chen, Y., Li, H., Zhao, C., Yang, Y., Hou, Y., Wang, C., \&
Li, N. (2011). Structural characterization and antioxidant properties of an exopolysaccharide produced by the mangrove endophytic fungus Aspergillus sp. Y16. Bioresource Technology, 102(17), 8179-8184. https://doi.org/10.1016/j.biortech.2011.06.048

Chi, C. F., Wang, B., Wang, Y. M., Zhang, B., \& Deng, S. G. (2015). Isolation and characterization of three antioxidant peptides from protein hydrolysate of bluefin leatherjacket (Navodon septentrionalis) heads. Journal of Functional Foods, 12(2015), 110. https://doi.org/10.1016/j.jff.2014.10.027

Costa, I. P. M. W., Maia, L. C., Cavalcanti, M. A. (2012). Diversity of leaf endophytic fungi in mangrove plants of northeast Brazil. Brazilian Journal of Microbiology, 1165-1173.

De Souza Sebastianes, F. L., Romão-Dumaresq, A. S., Lacava, P. T., Harakava, R., Azevedo, J. L., De Melo, I. S., \& Pizzirani-Kleiner, A. A. (2013). Species diversity of culturable endophytic fungi from Brazilian mangrove forests. Current Genetics, 59(3), 153-166. https://doi.org/10.1007/s00294-013-0396-8

Debbab, A., Aly, A. H., \& Proksch, P. (2013). Mangrove derived fungal endophytes - a chemical and biological perception. Fungal Diversity, 61(1), 127. https://doi.org/10.1007/s13225-013-0243-8

Deshmukh, S., Gupta, M., Prakash, V., Reddy, M. S., Deshmukh, S. K., Gupta, M. K., Prakash, V., \& Reddy, M. S. (2018). Mangrove-Associated Fungi: A Novel Source of Potential Anticancer Compounds. Journal of Fungi, 4(3), 101. https://doi.org/10.3390/jof4030101

Druzian, P.S., Pinheiro, N.L., Susin, N.M.B., Dal Pra V., Mazutti, M.A., Kuhn R.C., Terra L de M. 2019. Production of metabolites with antioxidant activity by Botryosphaeria dothidea in submerged fermentation. Bioprocess Biosyst.Eng.doi.org/10.1007/s00449-019-02200$\mathrm{y}$.

Ernst, M., Neubert, K., Mendgen, K.W., \& Wirsel SGR. (2011). Niche differentiation of two sympatric species of Microdochium colonizing the roots of common red. BMC Microbiol, 11, 242. doi:10.1186/1417-2180-11-242.

Ezhilan, B. P., \& Neelamegam, R. (2011). GC-MS analysis of phytocomponents in the ethanol extract of Polygonum chinense L . Pharmacognosy Research, 4(1), 11-15. https://doi.org/10.4103/0974-8490.91028

Gagkaeva, T.Y., Orina, A.S., Gavrilona, O.P., \& Gogina NN. (2020). Evidence of Microdochium fungi associated with cereal grains in Rusia. Microorganisms, $8, \quad 340$. https://doi.or/10.3390/microorganisms 8030340 
Hamed, I., Özogul, F., Özogul, Y., \& Regenstein, J. M. (2015). Marine Bioactive Compounds and Their Health Benefits: A Review. Comprehensive Reviews in Food Science and Food Safety, 14(4), 446-465. https://doi.org/10.1111/15414337.12136

Hamzah, T. N. T., Lee, S. Y., Hidayat, A., Terhem, R., Faridah-Hanum, I., \& Mohamed, R. (2018). Diversity and Characterization of Endophytic Fungi Isolated From the Tropical Mangrove Species, Rhizophora mucronata, and Identification of Potential Antagonists Against the Soil-Borne Fungus, Fusarium solani. Frontiers in Microbiology, $9, \quad 1707$. https://doi.org/10.3389/fmicb.2018.01707

Handayani, D., Rivai, H., Hutabarat, M., \& Rasyid, R. (2017). Antibacterial Activity of Endophytic Fungi Isolated from Mangrove Plant Sonneratia griffithii Kurz. Journal of Applied Pharmaceutical Science, $7(04)$,

209-212.

https://doi.org/10.7324/JAPS.2017.70431

Hernándes-Restrepo, M., Groenewald, J.Z., \& Crous, P.W. (2016). Taxonomic and phylogenetic reevaluation of Microdochium, Monographella and Idriella. Persoonia, 36, 57-82. https://doi.org/10.3767/003158516X688676

Hong, S.K., Kim, W.G., Choi, H.W., Lee SY. (2008). Identification of Microdochium bolleyi associated with basal rot of creeping bent grass in Korea. Mycobiology, 36(2), 77-80. https://doi.org/10.4489/MYCO.2008.36.2.077

Ibrahim, M., Kaushik, N., Sowemimo, A., Chippa, H., Koekemoer, T., Van de venter M., Odukoya, O. A. (2017). Antifungal and antipoliferative activities of endophytic fungi isolated from the leaves of Markhamia tomentosa. Pharmaceutical Biology, 55(1), 590-595. https://doi.org/ $\underline{10.1080 / 13880209.2016 .1263671}$

Kumar, S., Kaushik, N., \& Energy, T. (2013). Batch Culture Fermentation of Endophytic Fungi and Extraction of Their Metabolites. January, 1-6. https://doi.org/10.21769/BioProtoc.926

Li, J.-L., Sun, X., Chen, L., \& Guo, L.-D. (2016). Community structure of endophytic fungi of four mangrove species in Southern China. Mycology, 7(4), 180-190. https://doi.org/10.1080/21501203.2016.1258439

Liu, Y., Zachow, C., Raaijmakers, J.M., \& de Bruijn, I. (2016). Elucidating the diversity of aquatic Microdochium and Trichoderma species and their activity agains the fish pathogen Saprolegnia diclina. International Journal of Molecular Sciences, 17(1), 140-154. https://doi.org/ $\underline{10.3390 / \mathrm{ijms} 17010140}$

Manimaran, M., \& Krishnan, K. (2017). Marine Sp.
VITMK1 derived Pyrrolo [1,2-A] Pyrazine-1,4Dione, Hexahydro-3-(2-Methylpropyl) and its free radical scavenging activity. The Open Bioactive Compounds

https://doi.org/10.2174/1874847301705010023

Mukhlis, D. K., Rozirwan., \& Hendri, M. (2018). Isolasi dan aktivitas antibakteri jamur endofit pada mangrove rhizophora apiculata dari kawasan mangrove tanjung api-api kabupaten banyuasin sumatera selatan. Maspari Journal, 10(2), 151-160.

Patra, J. K., Das, G., \& Baek, K. H. (2015). Chemical composition and antioxidant and antibacterial activities of an essential oil extracted from an edible seaweed, Laminaria japonica L. Molecules, 20(7), 12093-12113. https://doi.org/10.3390/molecules200712093

Premathilaka, R., \& Silva, M. (2016). Bioactive Compounds and Antioxidant Activity of Bunchosia armenica. World Journal of Pharmacy and Pharmaceutical Sciences, 5(10), 1237-1247. https://doi.org/10.20959/wjpps201610-7783

Prihanto, A. A., Firdaus, M., \& Nurdiani, R. (2011). Endophytic Fungi Isolated from Mangrove (Rhyzopora mucronata) and Its Antibacterial Activity on Staphylococcus aureus and Escherichia coli. Journal of Food Science and Engineering, 1(2011), 386-389.

Radhakrishnan, C. A. E. K. (2017). Metabolite analysis of endophytic fungi from cultivars of Zingiber officinale Rosc . identifies myriad of bioactive compounds including tyrosol. 3 Biotech, 7(2), 110. https://doi.org/10.1007/s13205-017-0768-8

Rachman, F., Mubarik, N.R, Simanjuntak, P. (2018). Aktivitas antioksidan ekstrak kapang endofit cb.gm.b3 asal ranting kayu manis (Cinnamomum burmanni). Jurnal Bioteknologi \& Bioscience Indonesia, 5(2):204-213.

Rahman, M. M., Ahmad, S. H., Mohamed, M. T. M., \& Rahman, M. Z. A. (2014). Antimicrobial Compounds from Leaf Extracts of Jatropha curcas, Psidium guajava, and Andrographis paniculata. The Scientific World Journal. doi.org/10.1155/2014/635240

Rahmawati, S., Izzati, F., Yapsari, Y., Septiana, E., Rachman, F., Bustanussalam, \& Simanjuntak, P. (2019). Endophytic microbes and antioxidant activities of secondary metabolites from mangroves Avicennia marina and Xylocarpus granatum Endophytic microbes and antioxidant activities of secondary metabolites from mangroves Avicennia marina and Xylocarpus granatum. IOP Conf. Series: Earth and Enviromental Science. https://doi.org/10.1088/1755-1315/278/1/012065

Rajamanikyam, M., Vadlapudi, V., amanchy, R., 
Upadhyayula, S. M., Rajamanikyam, M., Vadlapudi, V., amanchy, R., \& Upadhyayula, S. M. (2017). Endophytic Fungi as Novel Resources of natural Therapeutics. Brazilian Archives of Biology and Technology, 60(0). https://doi.org/10.1590/1678-4324-2017160542

Sari, R. P., \& Hasibuan, M. P. (2017). Uji Potensi Antimikroba Biji Tumbuhan Mangrove (Avicennia Marina Sp.) Sebagai Upaya Pemberantas Penyakit Kepiting Bakau (Scylla Serrata). Jurnal IPA \& Pembelajaran IPA, 1(2), 113-120. https://doi.org/10.24815/jipi.v1i2.9685.

Strobel, G., Daisy, B., Castillo, U., \& Harper, J. (2004). Natural Products from Endophytic Microorganisms . Journal of Natural Products, 67(2), 257-268. https://doi.org/10.1021/np030397v

Tavadyan, L. A., Manukyan, Z. H., Harutyunyan, L. H., Musayelyan, M. V, Sahakyan, A. D., \& Tonikyan, H. G. (2017). Antioxidant Properties of Selenophene, Thiophene and Their Aminocarbonitrile Derivatives. Antioxidants. https://doi.org/10.3390/antiox6020022

Vijaya, T. (2017). Derived From Marine Fungal Endophytes ; a Review. Indo Amaerican Journal of Pharmaceutical Research, 7(01).

Wardani, S. H., Rismawan, T., \& Bahri, S. (2016). Aplikasi Klasifikasi Jenis Tumbuhan Mangrove Berdasarkan Karakteristik Morfologi Menggunakan Metode K-Nearest Neighbor (KNN) Berbasis Web. Coding Jurnal Komputer Dan Aplikasi Untan, 4(3), 9-21.
Wei, S., Lin, Y., Liao, M., Zhou, H., \& Li, Y. (2011). Characterization and Antioxidative Properties of Condensed Tannins from the Mangrove Plant Aegiceras corniculatum. Journal of Applied Polymer Science, 124, 2463-2472. https://doi.org/10.1002/app

Widowati, T., Sukiman, H., \& Simanjuntak, P. (2016). Isolasi dan identifikasi kapang endofit dari tanaman kunyit (Curcuma longa L) sebagai penghasil antioksidan. Biopropal Industri, 7(1), 916.

Yan, Z., Huang, C., Guo, H., Zheng, S., He, J., Lin, J., \& Long, Y. (2020). Isobenzofuranone monomer and dimer derivatives from the mangrove endophytic fungus Epicoccum nigrum SCNU-F0002 possess $\alpha$-glucosidase inhibitory and antioxidant activity. Bioorganic Chemistry, 94(November 2019), 103407. https://doi.org/10.1016/j.bioorg.2019.103407

Zhang, G., Sun, S., Zhu, T., Lin, Z., Gu, J., Li, D., \& Gu, Q. (2011). Antiviral isoindolone derivatives from an endophytic fungus Emericella sp. associated with Aegiceras corniculatum. Phytochemistry, 72(11-12), 1436-1442. https://doi.org/10.1016/j.phytochem.2011.04.014

Zhou, J., Diao, X., Wang, T., Chen, G., Lin, Q., Yang, X., \& Xu, J. (2018). Phylogenetic diversity and antioxidant activities of culturable fungal endophytes associated with the mangrove species Rhizophora stylosa and R. mucronata in the South China Sea. PloS One, 13(6), e0197359. https://doi.org/10.1371/journal.pone.0197359 